\title{
III. WYKORZYSTANIE NARZĘDZI CYFROWYCH W PROCESIE WYCHOWANIA W ŚWIETLE PROBLEMATYKI PRAWNEJ
}

Z perspektywy prawa kanonicznego rzeczywistość narzędzi cyfrowych w procesie wychowania można rozpatrywać w dwóch aspektach. Pierwszy, pozytywny, dotyczy możliwości, jakie dają narzędzia cyfrowe w chrześcijańskim wychowaniu, a w sposób szczególny w przygotowaniu do zawarcia związku małżeńskiego. Drugi aspekt, negatywny, związany jest z zagrożeniami, jakie niesie rzeczywistość wirtualna w kontekście zdolności do ważnego zawarcia związku małżeńskiego.

\section{Narzędzia cyfrowe w procesie przygotowania osób do zawarcia związku malżeńskiego}

Prawodawca Kodeksu Prawa Kanonicznego z 1983 r. w kan. 1063 zobowiązuje duszpasterzy do właściwego przygotowania wiernych do zawarcia związku małżeńskiego. ${ }^{1}$ Szczegółowe wskazania dotyczące tego zagadnienia zostały zamieszczona w Instrukcji Konferencji Episkopatu Polski o przygotowaniu do zawarcia matżeństwa w Kościele katolickim z 5 września 1986 r. Dodatkowo, każda biskup diecezjalny ma możliwość wydania szczegółowych norm w tym zakresie, na terenie własnej diecezji. ${ }^{2}$

1 KPK, kan. 1063: „Duszpasterze mają obowiązek troszczyć się o to, aby własna wspólnota kościelna świadczyła pomoc wiernym, dzięki której stan małżeński zachowa ducha chrześcijańskiego i będzie się doskonalił. Ta pomoc winna być udzielana przede wszystkim: 1. Poprzez przepowiadanie, katechezę odpowiednio przystosowaną dla małoletnich, młodzieży i starszych, także przy użyciu środków społecznego przekazu, dzięki czemu wierni otrzymają pouczenie o znaczeniu małżeństwa chrześcijańskiego, jak również o obowiązkach małżonków i chrześcijańskich rodziców; 2. Przez osobiste przygotowanie do zawarcia małżeństwa, przysposabiające nupturientów do świętości ich nowego stanu i jego obowiązków; 3. Przez owocne sprawowanie liturgii małżeństwa, która winna ukazywać, że małżonkowie są znakiem i zarazem uczestniczą w tajemnicy jedności oraz płodnej miłości Chrystusa i Kościoła; 4. Przez świadczenie pomocy małżonkom, ażeby wiernie zachowując i chroniąc przymierze małżeńskie, osiągali w rodzinie życie coraz bardziej święte i doskonałe".

2 W Diecezji Płockiej por. Instrukcja o przygotowaniu do małżeństwa i życia rodzinnego w Diecezji Płockiej z 2 II 2010 r.; por. http://www. duszpasterski. pl/1069,11. html (dostęp: 14 V 2015 ). 
Analiza Kodeksu Prawa Kanonicznego oraz Instrukcji Konferencji Episkopatu Polski pozwala stwierdzić, że możliwości, jakie dają narzędzia cyfrowe, nie jest w nich podjęta. Nie budzi to jednak zdziwienia, biorąc pod uwagę czas powstania tych dokumentów, tj. odpowiednio 1983 i 1986 rok. Lektura ustawodawstwa partykularnego, np. Instrukcji o przygotowaniu do matżeństwa i życia rodzinnego w Diecezji Płockiej, pozwala wysnuć podobny wniosek, choć ten dokument pochodzi z 2010 r. To wszytko prowadzi do konkluzji, że autorzy wymienionych dokumentów koncentrują się na bardziej na treści merytorycznej. Sposób przekazu tych treści pozostawiają natomiast do wyboru duszpasterzy, którzy mogą korzystać z metod wypracowanych np. w katechetyce i posługiwać się różnymi narzędziami w ich przekazie. Nie wydaje się konieczne, by dokumenty o charakterze typowo prawnym podejmowały tak szczegółowe zagadnienia, do jakich należą narzędzia przekazu konkretnych treści.

\section{Narzędzia cyfrowe w kontekście zdolności do zawarcia związku małżeńskiego}

Narzędzia cyfrowe i rzeczywistość wirtualna, sama w sobie, nie ma konkretnej wartości moralnej. Staje się natomiast dobra lub zła w zależności od sposobu, w jakim jest wykorzystywana. Nie sposób wymienić pozytywne możliwości wykorzystania narzędzi wirtualnych w życiu osoby lub społeczeństwa. Jednak należy również uświadomić sobie zagrożenia, jakie niesie ze sobą niewłaściwe jej używanie.

W orzecznictwie sądów kościelnych od jakiegoś czasu zaczęły pojawiać się wyroki orzekające nieważność małżeństwa z powodu uzależnienia od Internetu. Również w literaturze kanonistycznej został podjęty ten temat. ${ }^{3}$

3 Por. J. R o d ríg u e z Tor re n t e, Adicciones y matrimonio: influencia de las redes de Internet, w: AA. VV., VI Simposio de Derecho Matrimonial y Procesal Canónico, 1-3 de octubre de 2009, Granada 2009, s. 11-76; por. F. Q u a t $\mathrm{r}$ o n e, Dipendenza da Internet: rilevanza nelle cause matrimoniali di nullità, w: J. K o w a l, J. L 1 o b e 11 (red.), Iustitia et iudicium. Studi di diritto matrimoniale e processuale canonico in onore di Antoni Stankiewicz, Libreria Editrice Vaticana, Città del Vaticano 2010, s. 587-605; por. K. M i e r z e j e w s k i, Uzależnienie od Internetu jako przyczyna niezdolności do zawarcia malżeństwa w świetle prawa kanonicznego, Kraków 2011. 
Prawo kanoniczne wymaga, aby wolna wola osoby ${ }^{4}$ zawierającej związek małżeński była pozbawiona wad. W przypadku osoby uzależnionej np. od Internetu istnieje zaburzenie sfery wolitywnej, które skutkuje wadą zgody małżeńskiej. $\mathrm{W}$ takim przypadku mamy do czynienia $\mathrm{z}$ małżeństwem zawartym nieważnie.

Zagadnienie zagrożenia, jakie wynikają z niewłaściwego używania narzędzi wirtualnych w prawie kanonicznym, jest stosunkowo nowe. Należy również podkreślić, że jest ono otwarte i podlega rozwojowi, tak jak osiągnięcia technologii, które oferują coraz więcej możliwości korzystania z rzeczywistości wirtualnej.

ks. Tomasz Białobrzeski, Warszawa

\section{ROLA RODZICÓW W PROCESIE WYCHOWANIA DZIECKA DO ODBIORU ŚRODKÓW MASOWEGO PRZEKAZU}

Współczesne młode pokolenie w znacznym stopniu jest formowane przez środki społecznego przekazu i media elektroniczne. Statystyczny młody człowiek spędza każdego dnia wiele godzin przed telewizorem i komputerem. Jednocześnie maleje kontakt dzieci i młodzieży z rodzicami i innymi krewnymi, brakuje czasu, by rozmawiać ze sobą w sposób, który pomaga dojrzalej myśleć i wszechstronnie się rozwijać. U wielu młodych ludzi obserwuje się próbę ucieczki od rzeczywistości w świat miłych fikcji, które zapewnia wirtualna rzeczywistość. Szczególnym wyzwaniem wychowawczym stało się masowe upowszechnienie nieznanych poprzednim pokoleniom narzędzi usprawniających porozumiewanie się, zdalną współpracę i handel, rozpowszechnianie dzieł, idei, poglądów i opinii oraz ich ocenianie i komentowanie.

Przeznaczanie przez dzieci i młodzież zbyt wiele czasu na kontakt z mediami wprowadza ich w świat mitów o człowieku, wskazuje fikcyjne drogi do szczęścia, wytwarza sztuczne potrzeby w miejsce prawdziwych i nieodzownych do rozwoju. W tym kontekście, wśród pilnych zadań

4 KPK, kan. 1057: „§ 1. Małżeństwo stwarza zgoda stron między osobami prawnie do tego zdolnymi, wyrażona zgodnie z prawem, której nie może uzupełnić żadna ludzka władza. § 2. Zgoda małżeńska jest aktem woli, którym mężczyzna i kobieta w nieodwołalnym przymierzu wzajemnie się sobie oddają i przyjmują w celu stworzenia małżeństwa". 